\title{
Dissolved organic matter in agricultural soils
}

\author{
Bożena Smreczak*, Aleksandra Ukalska-Jaruga \\ Institute of Soil Science and Plant Cultivation - State Research Institute, Department of Soil Science Erosion and Land Conservation, \\ Czartoryskich St. 8, 24-100 Puławy, Poland \\ * Dr hab. inż. B. Smreczak, bozenas@iung.pulawy.pl, ORCID iD: https://orcid.org/0000-0001-8972-8636
}

Received: 27.07 .2020

Accepted: 07.01.2021

Associated editor: E. Błońska

\section{Keywords}

Agriculture

Soil

Soil organic matter

\begin{abstract}
The aim of the paper is to provide an overview on current knowledge on origin, structure, chemical composition and factors influencing dissolved organic matter (DOM) cycling in agricultural soils as well as it role in functioning of agroecosystems. DOM is considered as one of the most sensitive indicators of changes overlapping in the soil environment. It is the most mobile and active soil component serving as an easily available source of nutrients and energy for microbes and other living organisms. It participates in the soil forming processes, transports nutrients and pollutants into deeper soil horizons and actively supports processes of soil structure formation. DOM transformation in agroecosystems is impacted by many chemical, physical and biological factors and modified by climatic conditions and agricultural activities therefore the quantity and quality of DOM is very difficult to predict and control. Although, the role and the fluxes of DOM have been widely investigated in previous decades, but the research interest was focused mainly on forest soils and water reservoirs while less attention was paid to soils of agricultural usage. New challenges facing agriculture related to the protection of soil functions influencing ecosystem services, mitigation of climate changes and sequestration of organic carbon indicate DOM as a potential factor enabling to reach these goals.
\end{abstract}

\section{Introduction}

Soil organic matter (SOM) is one of the main parameters widely accepted as a measure for assessing quality and the overall health of soils (Bastida et al., 2006). It is a key component functionally and structurally integrated into basic terrestrial ecosystem processes and services. SOM is a mixture of simple and complex molecules also present in soil liquid phase. Dissolved organic matter (DOM) consists of polymer-like substances which are operationally defined as extracted with water or other extracting solutions may pass through a $0.45 \mu \mathrm{m}$ filter (Zsolnay, 2003; Bolan et al., 2011). The fraction exceeding diameter $0.45 \mu \mathrm{m}$ is termed as Particulate Organic Matter (POM).

DOM contains a huge amount of various organic compounds indicating wide range of molecular sizes and properties therefore in the literature there are many classifications which vary substantially. They often depend on the purpose of the study and the extraction technique (Tan, 2014). DOM can be divided to on substances truly dissolved in the soil solution and occurring in the colloidal form (Tan 2014). Moreover, it is fractionated on "labile DOM" and "stable DOM" fractions (Krull et al., 2003; Marschner and Kalbitz, 2003). Molecules occurring in intra-aggregate and macropore spaces, quickly and easily decomposed by microbes are considered as "labile DOM". "Stable DOM" refers to compounds present in micro- and some mezopores indicating smaller diameters than that of bacterial cells. Encapsulated compounds are protected from microbial degradation therefore indicate ability to remain in soils for the decades (Tegen and Dörr, 1996; Krull et al, 2003). Zsolnay (2003) proposed congenial classification of DOM due to location in soil pores indicating certain diameters, the mobility within the soil profile and availability to microbes. He has defined: DOM-I, DOM-II and DOM-III present in pores with diameters of: $<0.2 \mu \mathrm{m} ; 0.2-6 \mu \mathrm{m}$ and $>6 \mu \mathrm{m}$, respectively (Zsolnay, 2003). DOM-I is potentially available for microbes, DOM-II is available for microbes in situ but not mobile, while DOM III is available for microorganisms and mobile in soil profile. Regarding chemical nature, DOM has been separated into humified (HSs) and non-humified substances (NHSs). HSs include humic acids (HAs) and fulvic acids (FAs) while NHSs embrace aminosugars, carbohydrates, organic acids, proteins, phenols ect. (Wang et al., 2016). DOM creating compounds have also been classified according to the affinity to non-ionic and ion-exchange resins. Using XAD beads operationally defined hydrophobic neutrals, weak hydrophobic acids, strong hydrophobic acids, hydrophilic acids, hydrophilic neutrals and bases can be selected (Raber and Kögel-Knabner, 1997; Tan, 2014). Each of these fractions indicate different properties and behaviour in soils. Other DOM classification based on implemented separation technique 
on Amberlite resins qualify them as: colloidal, hydrophobic, transphilic and hydrophilic organic substances (Tan, 2014). Dissolved organic molecules may also be classified according to their origin on: autochtonous and allochtonous. The allochtonous soil DOM originates from secondary deposition of organic substances mostly transported with surface water runoff (Aiken et al., 2011).

DOM constitutes rather small part (up to a few percent) of the whole SOM pool (Table 1) but it is widely recognised as the most mobile and active soil component indicating on changes in soil processes, serving as a nutrient and energy source for microorganisms, affecting the soil negative charge denitrification process and acid base reactions in soil solution, influencing circulation of organic and inorganic contaminants in the global scale and playing a key role in the biogeochemical carbon cycle (Bowen et al., 2009; Kaiser and Kalbitz, 2012; Mitchell et al., 2013). Over past decades the content and transformations of DOM have been widely investigated. Majority of those studies concentrated on forest soils, sediments and water bodies (Karavanova et al., 2007; Burzyńska, 2012). Less attention was referred to agricultural soils. The expectations directed to the agriculture targeting on the reduction of carbon dioxide emission and increase of carbon sequestration in soils as well as protection of organic soils require new solutions to fulfil these goals. Some publications indicate on DOM as soil constituent supporting these actions. Therefore, the aim of the paper is to provide a current knowledge on origin, chemical composition, factors and processes influencing DOM role in agroecosystems in temperate climatic zone as well as present new solutions of DOM application in agriculture. In our publication DOM refers to dissolved organic carbon (DOC) which dominates $(>50 \%)$ in the pool of dissolved organic substances. The presented findings are regardless of the extraction technique.

\section{Sources and chemical composition of DOM}

In agricultural soils the major part of DOM is present in A horizon (Kaiser and Guggenberger, 2003; Rosa and Dębska, 2018) and consists of oxidatively altered, water-soluble intermediates of plant residue microbial decomposition, decaying animal tissues, animal excrements, exopolysaccharides released by microorganisms, products of bacteria and fungi cell lysis (Kaiser and Guggenberger, 2003). Plant exudates of organic origin and microbial egzoenzymes are also considered as significant sources of dissolved organic molecules (Kaiser and Guggenberger, 2003; Tan, 2014). Leaving post-harvest residues as well as natural fertilisers, sewage sludge, composts and biochar comprise additional sources of soluble organic substances in agricultural soils (Kaiser and Guggenberger, 2003; Kalisz et al., 2017; Rosa and Dębska,

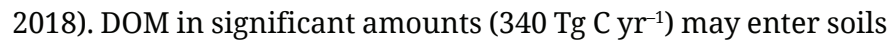
with rainwater (Willey et al., 2010) and to a lesser extent (1 and $10 \mathrm{ppm}$ ) with rain flushing organic substances from leaves and steams (Willey et al. 2010; Deb and Shukla 2011). Intensive mineralisation of organic matter in drained Histosols significantly contribute to the movement of DOM out of peatlands and enrichement in organic substances adjacent areas and/or surface waters (Burzyńska, 2012; Tunalay et al., 2017).
DOM composition and amount in soils vary substantially. Gregorich et al. (2001) and Filep and Rékási (2011) demonstrated that water-soluble $\mathrm{C}$ derived from "fresh" plant residues constitute only a part of the total DOM pool while $70-95 \%$ originate from native wet SOM. Gonet and Dębska (2008) have compared DOC content in various layers of agricultural and forest soils and they have noticed $150 \mathrm{mg} \cdot \mathrm{kg}^{-1}$ and $731 \mathrm{mg} \cdot \mathrm{kg}^{-1}$, respectively in 0-30 $\mathrm{cm}$ horizon while in $5 \mathrm{~cm}$ thick litter layer it comprised $5820 \mathrm{mg} \cdot \mathrm{kg}^{-1}$ (Table 1 ).

The occurrence of organic carbon in deeper soil horizons (B and C) results from e.g i) eluviation of DOM molecules from A horizon which occurs over much longer time scales than the lifetime of current vegetation and land use, ii) residues of decaying plant roots and iii) capillary ascension of organic substances dissolved in solutions circulated in soils (Bolan et al., 2011; Burzyńska, 2012; Tan, 2014; ). Bolan et al. (2011) reported that in mineral soils DOM content decreases by $50-90 \%$ with depth comparing to the amount present in A horizon. These records were also confirmed by Rosa and Dębska (2018) who studied DOC content in three depths: 0-30 cm; 30-60 cm and 60-90 cm of meadow and arable soils. The quantity of DOC in the depth of $30-60 \mathrm{~cm}$ constituted $36-72 \%$ and $79-81 \%$ while in the layer of $60-90 \mathrm{~cm}$ it amounted to $14-20 \%$ and $50-67 \%$, in meadow and agricultural soils, respectively as compared to the top layer (0-30 cm).

The elementary composition of DOM substances, except for carbon, include oxygen $(\mathrm{O})$, hydrogen $(\mathrm{H})$, nitrogen $(\mathrm{N})$, phosphorus (P), sulphur (S), and various cations (Karavanova et al., 2007; Tan, 2014). Despite DOM includes only six main elements, they form huge amount of organic substances indicating different configurations and spatial arrangements, spanning a range of molecular sizes and possessing functional groups varying with reactivity rates (Tan, 2014). DOM may consist of molecules ranging from a few hundred to over 100000 Da (Tan, 2014). They represent broad classes of aliphatic and aromatic compounds containing attached amino acids, ketones and amides (Bertilson and Jones, 2003). Part of DOM consists of polymeric sugars, lipids, amino acids and various monomeric organic substances representing groups of carbohydrates, peptides, proteins, and nucleic acids with molecular weight $<600$ Da (Bertilson and Jones, 2003). A significant part of DOM represent humic colloidal substances, forming organic and organo-mineral aggregates (Tan, 2014). The FAs extracted from agricultural soils fold a physically and chemically heterogeneous mixture of relatively low molecular weight organic molecules (200-500 Da) of both aliphatic and aromatic nature (Ukalska-Jaruga et al., 2018). FA molecules characterize high oxygen content accounting predominantly for carboxylic, phenolic, alcoholic and methoxyl functional groups while in HA molecules oxygen occurs as a nuclei structural component (Tan, 2014). HAs originated from agricultural soil demonstrated the highest content of oxygen and a higher degree of internal oxidation as compared to HAs from forest soil (Dębska and Gonet, 2008). The chemical structure of DOM may be influenced by organic amendments. Assmar et al. (1994) noted that application of sewage sludge may cause the increase of the FA heterogeneity by reduction of carboxylictype groups and increase of phenolic-type groups. Whereas, 
Table 1

Examples of dissolved organic matter share in soil organic matter of soils from farmland.

\begin{tabular}{|c|c|c|c|c|c|c|}
\hline Site & $\begin{array}{l}\text { Soil layer } \\
(\mathrm{cm})\end{array}$ & Other information & $\begin{array}{l}\text { TOC content } \\
\left(\mathrm{g} \cdot \mathrm{kg}^{-1}\right)\end{array}$ & $\begin{array}{l}\text { DOC* } \\
\left(\mathrm{mg} \cdot \mathrm{kg}^{-1}\right)\end{array}$ & $\%$ & Reference \\
\hline \multirow[t]{3}{*}{ cropland } & $0-15$ & Maize monoculture manured & 34.4 & 1226 & 3.56 & Gregorich et al., 2003 \\
\hline & & Maize monoculture no ammendment & 25.3 & 674 & 2.66 & \\
\hline & & Maize-soybean manured & 29.2 & 801 & 2.74 & \\
\hline forest & $0-30^{*}$ & - & 38.4 & 731 & 1.90 & Gonet and Dębska, 2008 \\
\hline croppland & & - & 12.0 & 150 & 1.25 & \\
\hline \multirow[t]{2}{*}{ croppland } & $0-30$ & Phaeozems & 7.65 & 62.8 & 0.82 & Rosa and Dębska, 2017 \\
\hline & & Luvisols & 7.24 & 61.3 & 0.85 & \\
\hline agricultural areas & $0-20$ & Soil Monitoring System of Hungary & 22.0 & 100.9 & 0.46 & Filep and Rékási, 2011 \\
\hline \multirow[t]{3}{*}{ croppland } & $0-10$ & Soil without amendments & 5.98 & 120.3 & 2.01 & Kalisz et al., 2017 \\
\hline & & Soil with sewage sludge at $30 \mathrm{t} \cdot \mathrm{ha}^{-1}$ & 5.83 & 127.3 & 2.18 & \\
\hline & & Soil with sewage sludge at $30 \mathrm{t} \cdot \mathrm{ha}^{-1}$ & 6.12 & 145.3 & 2.37 & \\
\hline
\end{tabular}

*average value

Garcia-Gil et al. $(2007,2008)$ evaluated that the long-term sludge and municipal waste composts application provoked an increase of FAs aliphacity, proton affinity of the carboxylic and phenolic groups as well as $\mathrm{N}, \mathrm{H}$, and S contents while decreased $\mathrm{O}$ content and $\mathrm{C} / \mathrm{N}$ ratios.

\section{Factors influencing DOM content in agricultural soils}

Soil DOM composition and content in agricultural soils result from a set of mutually interacting factors including: i) climatic conditions /the amount of atmospheric precipitation, soil temperature, drought/; ii) pedogenic parameters /pH, SOM content, cation-exchange capacity (CEC), electrical conductivity (EC), content of calcium carbonate $\left(\mathrm{CaCO}_{3}\right)$, soil texture/ iii) diversity of microorganisms and their enzymatic activity as well as iv) agricultural factors /type of land use, land use change, crop plant, crop rotation, cultivation systems, application of fertilisers and liming.

Climatic factors such as temperature and water are indicated as main "drivers" influencing DOM formation and fluxes. Seasonal changes of water content and temperature influence solubility of organic components but simultaneously microbial activity and desorption rate (Tunalay et al., 2017). Therefore, concentrations of organic compounds in a soil solution can vary over a short period of time (Tunalay et al., 2017; Rosa and Dębska, 2018). Longer precipitation periods and higher ground water level accelerate leaching and transportation of organic molecules within the soil profile while drought periods retard it substantially. Rosa and Dębska (2018) in a two-year study investigated seasonal changes of DOC in Phaeozems and Luvisols under various agricultural treatments: irrigation, application of mineral, natural and organic fertilizers, crop rotation. In the first year the highest content of DOC was reported in the late autumn and the lowest in the early spring while in the next year situation was opposite however the differences were not statistically significant. Higher soil moisture and temperature influenced microbial activity thus affected the rate of organic matter mineralization and humification. De Troyer et al. (2014) compared DOM content in 87 top soils with contrasting properties collected across the Europe. The samples were air dried, rewetted and kept in the cold temperature to simulate climatic factors which influence DOC formation in soils. Soil samples subjected to air drying and then kept rewetted for 5 weeks at $20^{\circ} \mathrm{C}$ indicated higher DOC content ( $45 \mathrm{mg} \cdot \mathrm{kg}^{-1}$ ) as compared with soils subjected to low temperature at $4^{\circ} \mathrm{C}$ for $1.5 \mathrm{yrs}$. and fresh soil samples which contained 22 and $21 \mathrm{mg} \cdot \mathrm{kg}^{-1}$ of DOC, respectively.

Pedogenic factors also substantially contribute to DOC formation, transformation and stabilization throughout: i) formation of insoluble organic compounds and their flocculation; ii) strong sorption and then encapsulation of DOM in SOM structures iii) complexation of organic molecules with polyvalent cations and iv) adsorption of dissolved C-rich substances onto reactive surfaces of clay minerals e.g. kaolinite, illite, montmorillonite, amorphous aluminium and iron oxides (Brockett et al., 2012; Luo et al., 2012; Avneri-Katz et al., 2017).

The significant influence of soil properties on DOM formation and content was confirmed by Filep and Rékási (2011) who investigated the impact of 14 factors on DOM amount in 190 Hungarian agricultural soils with different properties e.g $\mathrm{pH}_{\mathrm{KCl}}$ : 3.6-8.1; clay (\%): 2.8-61.6; SOM (\%): 0.5-5.3 while DOC content was in the range of $25.1-364.9 \mathrm{mg} \cdot \mathrm{kg}^{-1}$. Principal component analysis (PCA) indicated on the soluble $\mathrm{N}$, soil texture and soil acidity while results of multivariate regression analysis pointed on statistically significant positive influence of CEC, SOM and dissolved inorganic nitrogen (DIN) $(\beta=0.32,0.28$ and 0.21 , respectively; $R^{2}=0.389$ ) as factors determining DOC concentration. Kalbitz et al. (2000) indicated that the clay fraction played significant role in the decrease of DOM content whereas Singh et al. (2016) have recorded sorption capacity of clay minerals towards DOM maintaining the order: allophane $>$ smectite $>$ kaolinite-illite. McDowell (2003) noted that in mineral soils the 
adsorption of organic substances onto secondary mineral surfaces was more important for DOM movement in soil profile than input of plant drop or microbial activity. ${ }^{13} \mathrm{C}$ NMR studies carried out by Mitchell et al. (2013) confirmed those findings and indicated on the type of DOM-mineral interactions. Carboxylic functional groups exhibited affinity to colloidal aluminum and iron oxides, hydroxyl-containing O-alkyl components and carboxyl moieties to hematite surfaces, aromatic- and hydroxylcontaining moieties to montmorillonite while aromatic components to kaolinite. Moreover, they recorded similar preferential binding occurring in subsoil horizons while polar carbohydrate and peptide components stayed mobile in soil solution (Mitchell et al., 2013). Those reactions were not $\mathrm{pH}$-dependent.

Soil chemical properties influence the charge of DOM components. Filep and Rékási (2011) demonstrated positive significant relations between DOC and CEC related to a higher affinity of hydrophobic organic molecules to oxide/hydroxide soil components and their important role in DOM preservation against microbial transformations. They also pointed that higher values of soil EC caused a decrease of DOM content and explained these findings with an increase of ion concentrations in soil solution and reduction of net surface charge influencing the flocculation of organic substances and more effective DOM aggregation in the presence of bivalent and trivalent ions.

Soil acidity affects chemical characteristics of DOM (Bolan et al., 2011; Deb and Shukla, 2011; Curtin et al., 2016). Bolan et al., (2011) extracted DOM from soil samples artificially transformed to different $\mathrm{pH}$ values and found, that the amount of soluble organic compounds was positively correlated with $\mathrm{pH}$ values what was attributed to changes in the charge and sorption capacity of $\mathrm{Al} / \mathrm{Fe}$ sesquioxides and the mobility of DOM-Al and DOM-Fe complexes. Moreover, at low $\mathrm{pH}$ an increase of the lipophilic nature of humic substances was reported and DOM indicated tendency to coagulate (Bolan et al., 2011). Contradictory dependencies were recorded by De Troyer et al. (2014) who indicated that concentration of DOC in soil pore water was negatively correlated with $\mathrm{pH}, \%$ clay, $\%$ base saturation (BS) while positively with $\% \mathrm{OC}$ and $\% \mathrm{~N}$. The multiple regression models accounted for $14 \%$ to $65 \%$ of the variance.

Bacteria, fungi, protozoa and invertebrates create the decomposer community of SOM however fungi are considered as main organisms involved in DOM production because perform incomplete degradation of organic material (Zsolnay, 2003). In biologically active soils both, increase and decrease of DOM content can be observed (Leinweber et al., 2008; Rosa and Dębska, 2018). Soil microbial community cause degradation of SOM stock provoking the release of dissolved organic substances as well as mineralization of DOC to carbon dioxide (Leinweber et al., 2008). The input of fresh organic matter substantially modulate microbial activity. This may cause the increase of dissolved organic molecules but also result in the immobilization of more recalcitrant soil carbon fractions in A horizon (Mitchell et al., 2013). Amendment of agricultural soils with exogenous organic matter substantially changes the $\mathrm{C}: \mathrm{N}$ ratio, inoculates soils with new microbial communities and introduces a portion of soluble organic substances indicating certain properties (Brockett et al., 2012). It is believed that application of C-rich amendments in- creases the amount of water-soluble organic substances in A horizon and accelerates their movement into the depth of the soil profile. Some recent studies do not support these assumptions indicating the importance of amendment properties. Rosa and Dębska (2018) noticed that the application of natural fertilisers although increased amounts of extracted DOC but only in the surface layer and finally did not influence transportation to the deeper soil horizons. Sorrenti and Toselli (2016) also did not observe any significant increase of DOC concentration in leachates collected from the biochar-amended sandy soil as compared to an untreated control. Speratti et al. (2018) found that cotton and swine manure biochar caused an increase of dissolved organic substances in soils while eucalyptus and filter cake biochars rather retained a labile $C$ fraction. The findings were explained by different sorption affinities indicated by each kind of biochar (Speratti et al., 2018). Kalisz et al. (2017) investigated DOM changes in 0-10 cm layer of sandy soil after three years of municipal sewage and composted waste application at various doses (30-150 t $\left.\cdot \mathrm{ha}^{-1}\right)$. Generally, both improvements have increased the lability of the organic substances although some decline effects were also observed during the experimental period. Burzyńska (2012) demonstrated that the fresh, crumbled plant biomass left after grass cutting positively influenced DOC production but its transportation was substantially limited. That confirmed the concentration of the labile SOM fraction in the shallow ground waters being in the range 6.1 to $11 \mathrm{mg} \mathrm{DOC} \mathrm{dm}^{-3}$. The explanations pointed on grass root systems as an effective sorbent of organic molecules.

Application of mineral fertilisers, especially those providing $\mathrm{N}$ to soils, can indirectly influence increase of DOM production but modulate the $\mathrm{C}: \mathrm{N}$ ratio accelerating mineralization process. These chances are connected with the kind of crop plant, the amount and quality of post-harvest residues, the type of fertilizer being applied, soil properties, water availability and climate conditions. Formation of $\mathrm{NH}_{4} \mathrm{OH}$ after urea application may result in large changes in soil $\mathrm{pH}$, redox and oxygen conditions (O'Callaghan et al., 2010). Although, elevated pH in urea fertilized soils are transient (lasting for days to weeks only), periodically changing conditions may have important effects on both the solubility and leaching of soil $\mathrm{C}$ and on the intensity of microbial transformations (O'Callaghan et al., 2010). However, Burzyńska (2012) demonstrated that long term application of other $\mathrm{N}$ fertilizers like ammonium nitrate and calcium nitrate ultimately caused acidification of meadow soils, but finally increased DOM production. Wang et al. (2016) examined the impact of nitrogen fertilisation and crop growth on DOC content in soil solution at a maize-wheat rotated field. The results indicated on fertilization as stimulating the plant growth and not affecting the increase of DOC content and pointed on plants as directly influencing the DOC production. Rosa and Dębska (2018) have compared the effects of mineral fertilization $\left(<120 \mathrm{~kg} \mathrm{~N} \mathrm{ha}^{-1}\right.$ and $\left.>120 \mathrm{~kg} \mathrm{~N} \mathrm{ha}^{-1}\right)$ on DOC content in various depths $(0-30 \mathrm{~cm}, 30-60 \mathrm{~cm}$ and $60-90 \mathrm{~cm})$ of Phaeozems. The statistically significant differences in DOC amount as referred to applied doses were noted only for the 60-90 cm depth (46.31 $\mathrm{mg} \cdot \mathrm{kg}^{-1}$ and $36.96 \mathrm{mg} \cdot \mathrm{kg}^{-1}$, respectively) while for upper layers were in the range of $55.16-58.47 \mathrm{mg} \cdot \mathrm{kg}^{-1}$. 
Post-harvest plant residues significantly influence seasonal variability of DOC concentration (Wang et al., 2016). Qui et al. (2015) investigated the impact of crop residue-derived DOM on soil $\mathrm{CO}_{2}$ and $\mathrm{N}_{2} \mathrm{O}$ emissions as well as $\mathrm{C}$ sequestration under wheat cultivation. Part of winter wheat grown in pots under field condition were treated by adding water extracts of maize stalk (Qui et al., 2015). The results indicated increased $\mathrm{CO}_{2}$ and $\mathrm{N}_{2} \mathrm{O}$ emissions after DOM supply and reduced soil $\mathrm{C}$ sequestration comparing to the untreated control.

Land usage and its change indirectly and directly modifies DOM content in soils. Soil cultivation provides oxygen for microorganisms which causes the acceleration of the decomposition of organic matter (Gonet and Dębska, 2008; Bueno and Ladha, 2009). However, ploughing could also result in subsoil compaction causing the reduction of microbial biomass $C$ turnover and the slowing down the leaching of DOM (Gmach et al., 2020). The DOC fraction is more sensitive to tillage disturbance than total soil organic carbon pool. Thus, soils under no cover can suffer significant C losses as DOC forms (Baldock and Skjemstad, 2000). However Ukalska-Jaruga et al (2019) reported high percentage of DOM in arable soils than in grasslands.

Haynes (2000) observed positive significant correlations $(r=0.89-0.96)$ between the amount of labile organic matter and cropping history. Land use change from pasture used for over 2 years to arable land indicated declining DOM content. The study concluded that inclusion of grazed pastures in a cropping system positively maintains labile organic C (Haynes, 2000). Poepalau and Don (2013) investigated 24 paired sites across Europe to assess DOM changes to the depth of $80 \mathrm{~cm}$. Localisation of sampling points based on LUCAS programme considered the wide range of pedoclimatic conditions and comprised the major European land use types and their changes: cropland to grassland, grassland to cropland, cropland to forest and grassland to forest. According to their research, afforestation and grassland transition to croplands led to similar SOM gains and did not substantially contribute to DOM fluxes, but afforestation affects SOM mineralisation from stable to labile carbon pools, even at 50\% (Poepalau and Don, 2013).

Other environmental problem facing agriculture concerns peatlands degradation due to draining and transformation to arable land. The drying and oxygenating organic layers are significant sources of the carbon dioxide emissions in the regional and global scales but also DOC release creating one of the main groundwater contaminants (Poepalau and Don, 2013).

\section{Processes affecting DOM fluxes in agricultural soils}

DOM fluctuations in soils are influenced by various processes occurring simultaneously, which result in a balance between input and output of carbon in soil solution (Jansen et al., 2014). They can be divided into three main categories: i) biological processes regarding biodegradation/decomposition and biotransformation; ii) chemical processes relating to sorption, complexation and immobilisation iii) physical processes responsible for leaching of organic substances through the soil profile.
Dissolved organic substances occur as heterogeneous mixtures at varying concentrations in: i) interstitial water-bridging solid particles, ii) interlayer water, iii) hydration shells and iv) films around solutes and colloidal particles (Jansen et al., 2014; Tan 2014). Location of soluble organic compounds limits their availability, which is predominantly important for microorganisms. According to Marschner and Kalbitz (2003), biodegradation of DOM encompasses two processes: breakdown and/or uptake of original compounds used for the biosynthesis of microbial cell components and complete DOM mineralisation to acquire energy and inorganic nutrients. DOM may undergo microbial degradation with various time periods. Kalbitz et al. (2000) have calculated that $10 \%$ to $40 \%$ of the total DOC might undergo microbial transformation within a period of days to months. Similar results were presented by Bowen et al. (2009), who investigated DOM biodegradation in six soils incubated in laboratory conditions through 70 days. They have noted DOC changes from $11 \%$ up to $29 \%$. The microbial appearance varied among soils whilst the most intensive DOM degradation occurred during the first 15 days (Bowen et al., 2009). There is a limited number of studies regarding the amount of rapidly and slowly biodegradable DOM fractions and their mean residential times in agricultural soils. Hur et al. (2011) calculated a half-life for the rapidly degradable DOM pool reaching the range of 3-8 days while that of slowly degradable one varied from 0.4 to 6 years. This rate depended on DOM qualitative composition. Readily degraded fraction contained carbohydrate, protein and amino acids (Hur et al. 2011). Ogawa et al., (2001) also recorded that some DOM components like carbohydrates, e.g. glucose, may be transformed by bacteria into more stable compounds.

The dissolved organic fraction consists of compounds indicating various potential for sorption in the vadose zone. DOM can be immobilised in soil through molecular interactions, complexation, anion sorption, ligand exchange, protonation, hydrogen bonding, cation bridging and physical adsorption (Bolan et al., 2011; Deb and Shukla, 2011; Jansen et al., 2014). Adsorption of DOM and its accumulation in soils depends on the amount of available adsorption sites. Dissolved organic molecules are predominantly adsorbed on the exterior clay mineral surfaces therefore in some conditions they may be reversibly bound what results in their desorption to soil solution. Organic molecules may also replace the ions in secondary mineral surfaces but the intensity and efficiency of this process depends on the energy resulting from the size and the valence of the ion being replaced (Polubesova et al., 2007). Surface accumulation and stabilisation of dissolved organic matter within soil horizons was studied by Kaiser and Guggenberger (2003) who noticed that adsorption of organic substances is strongly positively enhanced by active mineral surfaces. The soil Brunauer-Emmett-Teller (BET) equation indicated on mineralogy as the primary factor controlling the relation between surface area and sorption of organic matter within the same soil compartments (i.e. horizons). It results in the creation of organic coatings and organo-mineral complexes which contribute to the accumulation of DOM e.g. in B horizon. Saturation of sorption sites by organic molecules reduces the sorption affinity of minerals making them unreactive. Some DOM fractions e.g. carbohydrates may be adsorbed to mineral surfaces 
mainly via $\mathrm{H}$ bonding and Van der Waals interactions (AvneriKatz et al., 2017), therefore parts of organic substances may desorb easily to soil solution thereby being available to microbes (Kaiser and Guggenberger, 2003; Avneri-Katz, 2017). Charge of hydrous $\mathrm{Fe}$ and $\mathrm{Al}$ oxides is $\mathrm{pH}$-dependent therefore in some soils dissolved organic compounds compete on sorption sites with ions and are bound via ligand-exchange (Kaiser and Guggenberger, 2003). Binding strength and potential release to soil solution depends also on DOM structure. Aromatic compounds indicating hydrophobic properties undergo strong adsorption as compared with those of aliphatic structure and hydrophilic nature. AvneriKatz et al. (2017) noted hydrophobic acids and hydrophilic neutral fractions containing - $\mathrm{COOH}$ groups and highly oxidised polyphenols to be preferentially adsorbed by mineral surfaces via ligand-exchange receptions protecting organic substances from chemical and biological degradation. Moreover, it is also unclear what mechanisms protect organic compounds against microbial and enzymatic degradation in soils (Kaiser and Guggenberger, 2003). The role of other mineral soil components like quartz cannot be excluded from consideration but they indicate less effective surface area and relatively low sorption affinity. Such minerals bind DOM via weak Van deer Waals forces therefore desorption of organic compounds will occur faster (Gmach et al., 2020). More information on DOM sorption/desorption processes were presented by Kaiser and Guggenberger (2003).

Desorption of DOC is an important process influencing C transportation deeper in soil profile down to groundwater reservoirs (Sapek, 2009; Cincotta et al., 2019). Adsorbed on mineral surfaces, chemically active DOM molecules create a real barrier preventing the movement of other dissolved organic substances because soil acts as chromatography columns filled with sorbents partitioning leaching compounds on fractions with varied properties (Sindh et al. 2016). It was noted by Kaiser and Guggenberger (2003) that compounds with hydrophilic properties are moved deeper into the soil profile while those of hydrophobic nature stay adsorbed in the upper soil layers. Strong adsorption of DOM deeper in soil profile was confirmed by Silveira Azevedo (2005) and Hamkalo and Bedernichek (2014) who noticed negative correlations between the net removal of hydrophobic acids and increasing soil depth. However Sosulski et al. (2013) has noticed higher DOC content in the deeper soil horizons than in the A layer of Luvisols. Those findings were more pronounced in spring than autumn and in soil fertilised with manure and manure with mineral fertilisers than in soil fertilised only with mineral fertilisers.

\section{The importance and the role of DOM in agricultural soils}

Better understanding of the formation and persistence processes (eg absorption, sequestration, coagulation) of DOM will be a real challenge for science and agriculture in the coming years. Protection of soil functions influencing ecosystem services provided by soils will require special attention for better understanding the interdependence and/or dependence of soil properties and dissolved carbon dynamics (Lefevre et al.,
2017). Carbon sequestration and limited GHG emissions from soil "hot spots" is also DOM-related problem of agricultural concern because DOM influences functions and ecological services provided by agricultural soils (Bolan et al., 2011). It directly and indirectly affects biochemical processes and microbial activity related to the production and habitat functions of soil as well as eluviation of nutrients and pollutants influencing its retention function.

It is very likely that part of a DOM fraction actively participates in the creation of the soil aggregate structure supporting the processes of its formation. DOM acts as a structuring binder for primary particles, clay minerals, and bacterial and fungal debris allowing the creation of extremely stable micro- and macroaggregates (Bolan et al., 2011). Therefore, the input of C-containing amendments significantly enhances soil physical resistance (Bolan et al., 2011). DOM influence on soil aggregation is not only restricted to A horizon because DOM-metal(oids) complexes are especially notable binding agents for aggregate formation in deeper B and C horizons. Recent studies indicated that the effectiveness of soil aggregate formation depends on DOM behaviour in relation to the ionic strength of soil solution rather than climatic factors, application of nitrogen fertilizers or land management practices. Cinciotta et al. (2019) reported that stability of DOM as a binding factor depends on ionic strength of soil solution. The increase of $\mathrm{pH}$ value indicated by divalent cations led to coagulation and the stabilization of organic material in soil horizons but in acidic conditions extractable DOC concentrations were significantly higher, aggregate diameters smaller and organic material was separated from mineral particles due to their dispersion (Cinciotta et al., 2019). These findings indicate that acidity is one of the main factors influencing stability or release of DOM. Therefore, cyclic liming is beneficial for maintaining DOM-origin carbon stock predominantly in acidic agricultural soils.

Recently, the stability of SOM in deeper soil layers has been presented as a very relevant and promising perspective underlying the role of agriculture in C sequestration. Rumpel et al. (2012) indicated DOM as the main source of C in deeper soil layers. They concluded that DOM fluxes were very difficult to quantify due to site-specific conditions, vegetation, soil types, temperature, moisture, aeration and soil structure but underlined that carbon present in subsoils contributed to more than a half of the $\mathrm{C}$ total stocks within a soil profile and indicated very high mean residential time of SOC reaching even thousands of years (Rumpel et al., 2012). Increased amounts of organic dissolved organic substances and organo-mineral complexes in deeper soil horizons can also lead to some negative effects changing physical and chemical properties of soils, especially in B horizon. Illuviated substances reduce the diameters of soil pores retarding water permeability and limiting carbon and nitrogen availability to aboveground production (Rumpel et al., 2012).

Over $90 \%$ of total soil $\mathrm{N}$ occurs in organic forms (Silveira Azevado, 2005). However, the availability of DOM-originated nutrients like $\mathrm{N}, \mathrm{P}$ and $\mathrm{S}$ for microbes and plants is still poorly recognised. DOM adsorbed on clay minerals may create a significant stock of them. Silveira Azevado (2005) indicated a difference in behaviour of DOM associated $\mathrm{C}, \mathrm{N}$ and P.. In agricultural 
soils the decomposition rate of DOM and bioavailability of nutrients may be substantially increased by the application of nitrate fertilisers. The $\mathrm{C}$ to $\mathrm{N}$ ratio as well as $\mathrm{C}$ to $\mathrm{P}$ ratio influence microbial activity and mineralization process. Moreover, DOM acts as a readily available carbon source for aerobic and anaerobic soil organisms. In anaerobic conditions the increase of the nitrate reduction (denitrification process) enhancethe release of the greenhouse gases: $\mathrm{N}_{2} \mathrm{O}$ and $\mathrm{NO}$ but simultaneously decreasing groundwater eutrophication with mineral N. Therefore, from an agriculture perspective, better understanding the role of DOM transformations in soils may also be important in terms of the possible alternation of nitrate transport into ground waters.

Dissolved organic molecules binding heavy metals, organic pollutants (e.g. polycyclic aromatic hydrocarbons - PAHs), pesticides and antibiotics accelerate or restrict their mobility in soil profiles thus, the movement to streams (Silveira Azevado, 2005; Sorrenti and Toselli, 2016). Lee et al. (2017) demonstrated in batch and column experiments the influence of dairy manure DOM on the sorption and transport of chlortetracycline (CTC), tylosin (TYL), and sulfamethazine (SMT) in two soils. Column transport experiments and the batch study results showed that elevated levels of DOM increased mass recovery and decreased retardation factors (R decrease from 890 to 371) of CTC and enhanced mobility of TYL and SMT. Mass recovery is the concentration of substance in the solution while retardation factor represents the ratio of the distance migrated by the sample compared to the distance traveled by the solvent front. Ukalska-Jaruga (2019) did not observe any significant relationship between the DOM and PAHs concentration in agricultural soils subjected to industrial emissions. However, pollutants present in available forms may be up taken by living organisms causing negative effects on their growth and development and/or accumulate into their tissue. $\mathrm{Li}$ et al. (2015) have noted that some groups of hydrophobic organic substances (HOCs )like organochlorine pesticides represented by methoxychlor indicated positive binding affinity to DOM while Pateiro-Moure et al. (2009) recorded that in the natural and processed (devoid of organic matter, and devoid of organic matter and free iron oxides) soils, adsorption isotherms of three herbicides: paraquat, diquat and difenzoquat were satisfactorily fitted to the Freundlich equation and their sorption affinity positively correlated with the amount of DOM. These findings are very important especially in case of areas where pesticides like organochlorine pesticides (OCPs) are still in use or were excessively used in the past. Raber and Kögel-Knabner (1997) compared DOM sorption affinity and potential to carry the (PAHs). They investigated DOM originated from soil (Ap horizon of Haplic Luvisol), sewage sludge for agricultural use and mature composts of cuttings from gardens and domestic wastes. They concluded that soil amendment with sewage sludge and compost had increased content of dissolved hydrophobic pollutants. Moreover DOM low molecular weight compounds (<1000 Da) dominated under field conditions and interact with PAHs due to their amphoteric properties.

DOM contains various substances of plant and bacterial origin e.g. saponins which reduce surface tension of soil solution and provoke better solubility and facilitate desorption of hydrophobic organic substances. Moreover, it was reported that addition of salicylic acid (a typical plant excaudate) to soils substantially accelerated the mineralization of pyrene, serving as the freely available source of carbon for soil microbes (Alagić and Maluckov, 2015). DOM binding toxic substances may be condensed on secondary mineral surfaces or/and bond to POM limiting pollutant availability and movement what results in decreasing of ecological risk caused by contaminants (Smreczak, 2018). DOM is acting as a carrying or retarding agent for many pollutants. The DOM carrying feature was applied for plant protection. Jia et al. (2019) demonstrated antifungal effects on pathogens after application of DOM-derived Se-enriched by-products. Authors concluded that such a product can be a potential ecological fungicide inhibiting the expansion and reducing the virulence of Sclerotinia sclerotiorum.

\section{Final remarks and research perspectives}

The paper presents issues governing the fluxes and the role of dissolved organic matter (fraction $<0.45 \mu \mathrm{m}$ ) in agricultural soils. DOM amount is controlled by various processes resulting in a balance between input and output of carbon in soil solution. They are modified by seasonal changes, soil conditions, biomass inflow, activity and composition of bacterial community and the type of land use. Therefore, the amount and composition of DOM differs substantially among soils and locations. There is a fundamental conflict between carbon sequestration and decomposition of soil organic matter providing nutrients and increasing DOM content in soils and water streams. Although, the significance of DOM in agricultural soils is partially recognized, still many processes and factors influencing its fluxes are not fully understood (Bowen et al., 2009). Therefore, the research directions and outlook should consider better understanding of processes which may be an opportunity for agriculture to implement more effective sequestration practices, develop new management strategies and innovative technologies for more effective management of dissolved organic matter resources in soils. Although, it is already known that DOM is a source of $\mathrm{N}$ and $\mathrm{P}$, there is a real urgency to study the interdependences which govern mobilization and immobilization of those elements in soils. Some agricultural areas are contaminated with organic and inorganic substances what indicate the need to increase the available knowledge related to the risk assessment and risk management scenarios especially related to the availably of pollutants to living organisms and their possible migration with DOM into deeper soil layers. Control of processes such as microbial activity on local and regional scales, implementation of the best DOM sequestration practices and reliably estimate $C$ budgets will be real challenges for the science and agriculture in the near future.

\section{Acknowledgement}

We kindly acknowledge task 1.3 "Monitoring of various soil parameters for a proper evaluation of the Common Agricultural Policy”, Multiannual Program (2016-2020) of IUNG-PIB coordinated by Ministry of Agriculture and Rural Development of Poland. 


\section{References}

Aiken, G.R., Hsu-Kim, H., Ryan, J.N., 2011. Influence of dissolved organic matter on the environmental fate of metals, nanoparticles, and colloids. Environmental Science and Technology 45(8), 3196-3201. https://doi.org/10.1021/es103992s

Alagić, S.Č., Maluckov, B.S., Radojičić, V.B., 2015. How can plants manage polycyclic aromatic hydrocarbons? May these effects represent a useful tool for an effective soil remediation? A review. Clean Technologies and Environmental Policy 17, 597-614. https://doi.org/10.1007/ s10098-014-0840-6

Assmar, F., Eiland, F., Nielson, N.E., 1994 Biology and Fertility of Soils 17, 32-28. https://doi.org/10.1007/BF00418669

Avneri-Katz, S., Young, R.B., McKenna, A.M., Chen, H., Corilo, Y.E., Polubesova, T., Borch, T., Chefetz, B., 2017. Adsorptive fractionation of dissolved organic matter (DOM) by mineral soil: Macroscale approach and molecular insight. Organic Geochememistry 103, 113-124. https://doi.org/10.1016/j.orggeochem.2016.11.004

Bastida, F., Moreno, J.L., Hernández, T., García, C., 2006. Microbiological activity in a soil 15 years after its devegetation. Soil Biology and Biochemistry 38, 2503-2507. https://doi.org/10.1016/j.soilbio. 2006.02.022

Bertilson, S., Jones, J.B. Jr., 2003. Supply of dissolved organic matter to aquatic ecosystems: Autochthonous sources. In S.E. G. Findlay and R.L. Sinsabaugh, eds. Aquatic ecosystems: interactivity of dissolved organic matter. Academic Press, San Diego, 3-24.

Bolan, N.S., Adriano, D.C., Kunhikrishnan, A., James, T., McDowell, R., Senesi, N., 2011. Dissolved organic matter: biogeochemistry, dynamics, and environmental significance in soils. In: Sparks, D.L. (Ed.), Advances in Agronomy 110. Elsevier Academic Press Inc, San Diego, 1-75. https://doi.org/10.1016/B978-0-12-385531-2.00001-3

Bowen, S.R., Gregorich, E.G., Hopkins, D.W., 2009. Biochemical properties and biodegradation of dissolved organic matter from soils. Biology and Fertility of Soils 45(7), 733-742. https://doi.org/10.1007/s00374009-0387-6

Brockett, B.F.T., Prescott, C.E., Grayston, S.J., 2012. Soil moisture is the major factor influencing microbial community structure and enzyme activities across seven biogeoclimatic zones in western Canada. Soil Biology and Biochemistry 44, 9-20. https://doi.org/10.1016/ j.soilbio.2011.09.003

Bueno, C., Ladha, J.K., 2009. Comparison of soil properties between continuously cultivated and adjacent uncultivated soils in rice-based systems. Biology and Fertility of Soils 45(5), 499-509. https://doi. org/10.1007/s00374-009-0358-y

Burzyńska, I., 2012. Zawartość rozpuszczalnego węgla organicznego w mineralnej glebie i w płytkich wodach gruntowych na tle sposobu użytkowania łąki. Polish Journal of Agronomy 8, 3-8.

Cincotta, M.M, Perdrial, J.N., Shavitz, A., Libenson, A., Landsman-Gerjoi, M., Perdrial, N., Armfield, J., Adler, T., Shanley, J.B., 2019. Soil aggregates as a source of dissolved organic carbon to streams: an experimental study on the effect of solution chemistry on water extractable carbon. Frontiers in Environmental Science 7, 1-14. https://doi. org/10.3389/fenvs.2019.00172

Curtin, D., Peterson, M., Anderson, C., 2016. pH-dependence of organic matter solubility: Base type effects on dissolved organic C,N,P, and S in soils with contrasting mineralogy. Geoderma 271, 161-172. https:// doi.org/10.1016/j.geoderma.2016.02.009

De Troyer, I., Merckx, R., Amery, F., Smolders, E., 2014. Factors controlling the dissolved organic matter concentration in pore waters of agricultural soils. Vadose Zone Journal 13, 1-8. https://doi.org/10.2136/ vzj2013.09.0167

Deb, S.K., Shukla, M.K., 2011. A Review of Dissolved Organic Matter Transport Processes Affecting Soil and Environmental Quality. Journal of Environmental and Analytical Toxicology 1 (02), 106. https://doi. org/10.4172/2161-0525.1000106
Filep, T., Rékási, M., 2011. Factors controlling dissolved organic carbon (DOC), dissolved organic nitrogen (DON) and DOC/DON ratio in arable soils based on a dataset from Hungary. Geoderma 163, 312-318. https://doi.org/10.1016/j.geoderma.2011.03.002

Garcia-Gil, J.C., Plaza, C., Fernandez, J.M., Senesi, N., and Polo, A., 2008. Soil fulvic acid characteristics and proton binding behavior as affected by long-term municipal waste compost amendment under semiarid environment. Geoderma 146, 363-369. https://doi.org/10.1016/ j.geoderma.2008.06.009

Garcia-Gil, J.C., Plaza, C., Senesi, N., Brunetti, G., and Polo, A., 2007. Effects of Long-Term Sewage Sludge Amendment on the Composition, Structure and Proton Binding Activity of Soil Fulvic Acids. Clean 35, 480-487. https://doi.org/10.1002/clen.200720013

Gmach, M.R., Cherubin, M.R., Kaiser, K., Cerri, C.E.P., 2020. Processes that influence dissolved organic matter in the soil: a review. Scientia Agricola. https://doi.org/10.1590/1678-992x-2018-0164

Gonet, S., Dębska, B., 2008. Dissolved organic carbon and dissolved nitrogen in soil under different fertilization treatments. Plant, Soil and Environment 52(2), 55-63. https://doi.org/10.17221/3346-PSE

Gregorich, E.G., Drury, C.F., Baldock, J.A., 2001. Changes in soil carbon under long-term maize in monoculture and legume-based rotation. Canadian Journal of Soil Science 81, 21-31. https://doi.org/10.4141/ S00-041

Hamkalo, Z., Bedernichek, T., 2014. Total, cold and hot water extractable organic carbon in soil profile: impact of land-use change. ZemdirbysteAgriculture 101(2), 125-132. https://doi.org/10.13080/z-a.2014.101.016

Haynes, R.J., 2000. Labile organic matter as an indicator of organic matter quality in arable and pastoral soils in New Zealand. Soil Biology and Biochemistry 32(2), 211-219. https://doi.org/10.1016/S00380717(99)00148-0

Hur, J., Lee, B.-M., Shin, H.-S., 2011. Microbial degradation of dissolved organic matter (DOM) and its influence on phenanthrene-DOM interactions. Chemosphere 85, 1360-1367. https://doi.org/10.1016/j.che mosphere.2011.08.001

Jansen, B., Kalbitz, K., Mc Dowell, W., 2014. Dissolved Organic Matter: Linking Soils and Aquatic Systems. Vadose Zone Journal 13(7), 1-4. https://doi.org/10.2136/vzj2014.05.0051

Jia, W., Hu, C.X., Xu, J.Y., Ming, J.J., Zhao, Y.Y., Cai, M.M., Sun, X.C., Liu, X.W., Zhao, X.H., 2019. Dissolved organic matter derived from rape straw pretreated with selenium in soil improves the inhibition of Sclerotinia sclerotiorum growth. Journal of Hazardous Materials 369, 601-610. https://doi.org/10.1016/j.jhazmat.2019.02.055

Kaiser, K., Guggenberger, G., 2003. Mineral surfaces and soil organic matter. European Journal of Soil Science 54, 219-236. https://doi. org/10.1046/j.1365-2389.2003.00544.x

Kaiser, K., Kalbitz, K., 2012. Cycling downwards - dissolved organic matter in soils. Soil Biology and Biochemistry 52, 29-32. https://doi. org/10.1016/j.soilbio.2012.04.002

Kalbitz, K., Solinger, S., Park, H.J., Michalzik, B., Matzner, E., 2000. Controls on the dynamic of the dissolved organic matter in soils: a review. Soil Science 165, 277-304.

Kalisz, B., Łachacz, A., Głażewski, R., Grabowski, K., 2017. Labile organic carbon fractions after amendment of sandy soil with municipal sewage sludge and compost. Journal of Elementology 22(3), 785-797. https://doi.org/10.5601/jelem.2017.22.1.1264

Karavanova, E.I., Belyanina, L.A., Stepanov, A.A., 2007. Water-soluble organic matter and soil solution acidity in the main soil types of the central forest state biosphere reserve. Eurasian Soil Science 40, 493-504. https://doi.org/10.1134/S1064229307050043

Krull, E.S., Baldock, J.A., Skjemstad, J.O., 2003. Importance of mechanisms and processes of the stabilization of soil organic matter for modelling carbon turnover. Functional Plant Biology 30 (2), 207-222. https://doi. org/10.1071/FP02085

Lee, J., Seo, Y., Essington, M., 2017. Sorption and Transport of Veterinary Pharmaceuticals in Soil-A Laboratory Study. Soil Science Soci- 
ety of America Journal, 78(5) 1531-1543. https://doi.org/10.2136/sssaj2013.11.0490

Lefevre, C., Rekik, F., Alcantara, V., Wiese, L., 2017. Soil organic carbon the hidden potential. Ed. Dandro F., Alcantara V., Baritz R., Vargas R. Food and Agriculture Organization of the United Nations, Rome, pp: 78.

Leinweber, P., Jandl, G., Baum, C., Eckhardt, K.U., Kandeler, E., 2008. Stability and composition of soil organic matter control respiration and soil enzyme activities. Soil Biology and Biochemistry 40, 1496-1505. https://doi.org/10.1016/j.soilbio.2008.01.003

Li, Y.-L., He, W., Liu, W.-X., Kong, X.-Z., Yang, B., Yang, C., Xu, F.-L., 2015. Influences of binding to dissolved organic matter on hydrophobic organic compounds in a multi-contaminant system: Coefficients, mechanisms and ecological risks. Environmental Pollution 206, 461-468. https://doi.org/10.1016/j.envpol.2015.07.047

Luo, L., Lin, S., Huang, H., Zhang, S., 2012. Relationships between aging of PAHs and soil properties. Environmental Pollution 170, 177-182. https://doi.org/10.1016/j.envpol.2012.07.003

Marschner, B., Kalbitz, K., 2003. Controls of bioavailability and biodegradability of dissolved organic matter in soils. Geoderma 113(3-4), 211-235. https://doi.org/10.1016/S0016-7061(02)00362-2

McDowell, W.H., 2003. Dissolved organic matter in soils - future directions and unanswered questions. Geoderma 113, 179-186. https://doi. org/10.1016/S0016-7061(02)00360-9

Mitchell, P.J., Simpson, A.J.,, Soong, R., Oren, A., Chefetz, B., Band Simpson, M.J., 2013. Solution-state NMR investigation of the sorptive fractionation of dissolved organic matter by alkaline mineral soils. Environmental Chemistry10, 333-340. https://doi.org/10.1071/EN13052

O’Callaghan, M., Gerard, E.M., Carter, P.E., Lardner, R., Sarathchandra, U., Burch, G., Ghani, A., Bell, N., 2010. Effect of the nitrification inhibitor dicyandiamide (DCD) on microbial communities in a pasture soil amended with bovine urine. Soil Biology and Biochemistry 42, 1425-1436. https://doi.org/10.1016/j.soilbio.2010.05.003

Ogawa, H., Amagai, Y., Koike, I., Kaiser, K., Benne, R., 2001. Production of refractory dissolved organic matter by bacteria. Science 292, 917-920. https://doi.org/10.1126/science.1057627

Pateiro-Moure, M., Pérez-Novo, C., Arias-Estévez, M., Rial-Otero, R., Simal-Gándara, J., 2009. Effect of organic matter and iron oxides on quaternary herbicide sorption-desorption in vineyard-devoted soils. Journal of Colloid Interface Science 333(2), 431-438. https://doi. org/10.1016/j.jcis.2009.02.019

Poepalau, C., Don, A., 2013. Sensitivity of soil organic carbon stocks and fractions to different land-use changes across Europe. Geoderma 192, 189-201. https://doi.org/10.1016/j.geoderma.2012.08.003

Polubesova, T., Sherman-Nakache, M., Chefetz, B., 2007. Binding of pyrene to hydrophobic fractions of dissolved organic matter: effect of polyvalent metal complexation. Environmental Science and Technology 41, 5389-5394. https://doi.org/10.1021/es070722r

Qiu Q, Wu L, Ouyang, Z., Li, B., Xu,Y., Wu, S., Gregorich, E.G., 2015. Effects of plant-derived dissolved organic matter (DOM) on soil CO2 and N2O emissions and soil carbon and nitrogen sequestrations. Applied Soil Ecology 96, 122-130. https://doi.org/10.1039/c6em00093b

Raber, B., Kögel-Knabner, I., 1997. Influence of origin and properties of dissolved organic matter on the partition of polycyclic aromatic hydrocarbons (PAHs). European Journal of Soil Science 48, 443-455.

Rosa, E., Dębska, B., 2018. Seasonal changes in the content of dissolved organic matter in arable soils. Journal of Soils and Sediments 18(8), 2703-2714. https://doi.org/10.1007/s11368-017-1797-y
Rumpel, C., Chabbi, A., Marschner, B., 2012.Cabon storage and sequestration in subsoils horizons: knowledge, gaps and potentials. R. Lal (eds.), Recarbonization of the Biosphere: Ecosystems and Global Carbon Cycle. Springer Science+Business Media B.V., 445-464. http:// doi-org-443.webvpn.fjmu.edu.cn/10.1007/978-94-007-4159-1_20

Sapek, A., 2009. Dissolved organic carbon in water from peat soil on Lawki Mire. Roczniki Gleboznawcze - Soil Science Annual, 60(2), 89-101.

Silveira Azevedo, M.L., 2005. Dissolved organic carbon and bioavailability of $\mathrm{N}$ and $\mathrm{P}$ as indicators of soil quality. Agricultural Science 62(5), 502-508. https://doi.org/10.1590/S0103-90162005000500017

Singh, M., Sarkar, B., Biswas, B., Churchman, J., Bolan, N.S., 2016. Adsorption-desorption behavior of dissolved organic carbon by soil clay fractions of varying mineralogy. Geoderma 280, 47-56. https://doi. org/10.1016/j.geoderma.2016.06.005

Smreczak, B., 2018. Biodostępność wielopierścieniowych węglowodorów aromatycznych (WWA) w glebach. Monografie i Rozprawy naukowe. Instytut Uprawy Nawożenia i Gleboznawstwa - Państwowy Instytut Badawczy, 56, 107 pp.

Sorrenti, G., Toselli, M., 2016. Soil leaching as affected by the amendment with biochar and compost. Agriculture, Ecosystems and Environment 226, 56-64. https://doi.org/10.1016/j.agee.2016.04.024

Sosulski, T., Szara, E., Stępień, W., 2013. Dissolved organic carbon in Luvisol under different fertilization and crop rotation. Roczniki Gleboznawcze - Soil Science Annual 64(3), 114-119. https://doi. org/10.2478/ssa-2013-0015

Speratti, A.B., Johnson, M.S., Sousa, H.M., Dalmagro, H.J., Couto, E.G., 2018. Biochar feedstock and pyrolysis temperature effects on leachate: DOC characteristics and nitrate losses from a Brazilian Cerrado Arenosol mixed with agricultural waste biochars. Journal of Environmental Management 211, 256-268. https://doi.org/10.1016/ j.jenvman.2017.12.052

Tan, K.H., 2014. Humic matter in soil and environment. In: Principles and controversies, CRC Press, Taylor and Francis Group, 79-104.

Tegen, I., Dörr, H., 1996. ${ }^{14} \mathrm{C}$ measurements of soil organic matter, Soil $\mathrm{CO}_{2}$ and dissolved organic carbon (1987-1992). Radiocarbon 38(2), 247-251. https://doi.org/10.1017/S0033822200017628

Ukalska-Jaruga, A., Debaene, G., Smreczak, B., 2018. Particle and structure characterization of fulvic acids from agricultural soils. Journal of Soils and Sediments 8, 2833-2843. https://doi.org/10.1007/s11368018-2008-1

Ukalska-Jaruga, A., Klimkowicz-Pawlas, A., Smreczak, B., 2019. Contributions of organic matter fractions in the top layer of soils under different land uses in Central-Eastern Europe. Soil Use and Management. Soil Use and Management 35(4), https://doi.org/10.1111/ sum.12514

Wang, X-G., Li, CH-S., Luo, Y., Hua, K-K., 2016. The impact of nitrogen amendment and crop growth on dissolved organic carbon in soil solution. Journal of Mountain Science 13(1), 95-103. https://doi. org/10.1007/s11629-015-3556-0

Willey, J.D., Kieber, R.J., Eyman, M.S., Brooks Avery Jr., G., 2010. Rainwater dissolved organic carbon: Concentrations and global flux. Global Biogeochemical Cycles 14(1), 139-148. https://doi.org/10.1029/ 1999GB900036

Zsolnay, A., 2003. Dissolved organic matter: Artefacts, definitions, and functions. Geoderma 113(3-4), 187-209. https://doi.org/10.1016/S00167061(02)00361-0 
Rozpuszczona materia organiczna w glebach rolniczych

\section{Słowa kluczowe}

Rolnictwo

Gleba

Glebowa materia organiczna

\section{Streszczenie}

Celem artykułu jest przedstawienie aktualnej wiedzy na temat pochodzenia, budowy chemicznej, składu chemicznego, oraz czynników wpływających na obieg rozpuszczalnej materii organicznej (RMO) w glebach rolniczych jak również jej roli w prawidłowym funkcjonowaniu agroekosystemów. RMO jest definiowana operacyjnie jako frakcja materii organicznej gleb ekstrahowana z zastosowaniem wody lub innych roztworów ekstrakcyjnych, przechodząca przez filtr $\phi<0,45 \mu \mathrm{m}$. RMO) jest uważana za jeden z wskaźników najbardziej wrażliwych na zmiany zachodzące w środowisku glebowym. Jest dynamicznym i aktywnym składnikiem gleby, ponieważ stanowi źródło łatwo przyswajalnych składników pokarmowych i węgla dla drobnoustrojów glebowych oraz innych organizmów żywych, uczestniczy w procesach glebotwórczych, transportuje składniki odżywcze i zanieczyszczenia w głąb profilu glebowego oraz wpływa na tworzenie się struktury agregatowej gleb. Zawartość i aktywność RMO w środowisku glebowym jest uwarunkowana wieloma czynnikami chemicznymi, fizycznymi i biologicznymi oraz warunkami klimatycznymi i działalnością rolniczą. Pomimo, że w poprzednich dziesięcioleciach rola RMO w środowisku przyrodniczym była przedmiotem wielu prac naukowych, jednak zainteresowania badawcze koncentrowały się głównie wokół gleb leśnych i zbiorników wodnych, natomiast mniej uwagi poświęcano funkcji RMO w glebach rolniczych. Nowe wyzwania stojące przed nauką i rolnictwem, związane z ochroną funkcji, które wpływają na usługi ekosystemowe gleb, łagodzenie zmian klimatycznych, w tym sekwestracja węgla organicznego, wskazują na DOM jako potencjalny czynnik umożliwiający osiągnięcie tych celów. 